\title{
PENGEMBANGAN INSTRUMEN TES KEMAMPUAN BERPIKIR KRITIS MAHASISWA PADA POKOK BAHASAN KINEMATIKA
}

\author{
Nanda Mas'ula ${ }^{1}$, Tria Ainur Rokhis ${ }^{2}$ \\ Pendidikan Fisika, FMIPA, Universitas Negeri Malang, Jl. Semarang 5, Malang ${ }^{1}$ \\ Fisika, FMIPA, Universitas Brawijaya, Jl. Veteran, Malang ${ }^{2}$ \\ Email: nandamasula5@gmail.com ${ }^{1}$
}

\begin{abstract}
Abstrak
Penelitian ini merupakan jenis penelitian \& pengembangan yang bertujuan untuk mengembangkan instrumen tes kemampuan berpikir kritis. Model penelitian yang digunakan adalah model ADDIE yang terdiri dari lima tahap, yaitu penganalisisan, perencanaan, pengembangan, pengimplementasian, dan pengevaluasian, namun penelitian ini dibatasi sampai tahap pengimplementasian. Instrumen tes yang dikembangkan berupa soal uraian berjumlah lima butir soal kemudian divalidasi sebanyak dua kali, yaitu validasi isi dan validasi empiris. Pada validasi isi diperoleh rata-rata nilai butir soal tes sebesar 3,30 , sedangkan pada validasi empiris menunjukkan kelima butir soal dikategorikan valid dengan nilai koefisien Cronbach Alpha sebesar 0,67. Hasil implementasi tes menunjukkan bahwa rata-rata nilai kemampuan berpikir kritis mahasiswa sebesar 9,71 dari 20,00 $\left(S_{D}=5,50\right)$ dengan nilai tertinggi 20,00 dan nilai terendah 1,00 . Hasil ini menunjukkan bahwa kemampuan berpikir kritis mahasiswa masih tergolong rendah.
\end{abstract}

Kata Kunci: Kemampuan berpikir kritis, isntrumen, kinematika

\begin{abstract}
This research is a research \& development research to develop critical thinking skills test instruments. The research model used is the ADDIE model that consists of five stages, namely analysing, planning, developing, implementing, and evaluating, however this research is limited to the implementation stage. The test instrument developed was in the form of a descriptive item consisting of five items and then validated twice, namely content validation and empirical validation. In content validation, the average value of the test items was 3.30, while empirical validation showed that those five items were valid with a Cronbach Alpha coefficient of 0.67. The results of the test implementation showed that the average value of students' critical thinking skills was 9.71 out of $20.00\left(S_{D}=5.50\right)$ with the highest value of 20.00 and the lowest value of 1.00. These results indicate that students' critical thinking skills are still relatively low.
\end{abstract}

Keywords: Critical thinking skills, instruments, kinematics

\section{PENDAHULUAN}

Kualitas pendidikan saat ini sangat mendapat perhatian dari berbagai kalangan. Hal ini dikarenakan pendidikan yang berkualitas merupakan suatu upaya agar dapat berkiprah di era globalisasi dan dapat berhadapan dengan tantangan yang akan datang di masa depan. Sehingga, dikarenakan kebutuhan masyarakat yang terus berkembang sangat menuntut pendidikan agar selalu relevan dengan segala bentuk kebutuhan tersebut. Hal ini merupakan dampak dari adanya perkembangan ilmu pengetahuan dan teknologi [1], [2].
Perkembangan IPTEK yang sangat cepat menjadi salah satu ciri era globalisasi abad ke-21 saat ini, sehingga menjadikan individu mudah untuk menemukan banyak informasi dari berbagai sumber. Dari sekian banyak sumber tersebut, maka setiap individu harus bisa menganalisa setiap informasi yang diperoleh, sehingga dapat memutuskan informasi tersebut ditolak atau diterima [3]. Oleh karena itu, dalam memilah informasi ini maka diperlukan suatu kemampuan yaitu kemampuan berpikir kritis. Kemampuan berpikir kritis juga merupakan salah satu kemampuan yang diperlukan dalam proses belajar, 
seperti pada proses pembelajaran Ilmu Pengetahuan Alam (IPA).

Presseisen menyebutkan bahwa aktivitas mental dengan tujuan untuk memperoleh suatu pengetahuan merupakan suatu bentuk kegiatan berpikir [4]. Sehingga, berpikir dapat diartikan sebagai suatu kegiatan yang dengan melalui proses kognitif yang tidak tampak secara fisik. Namun, produknya dapat berbagai macam seperti berupa ide, pengetahuan, prosedur, argument, keputusan dan lain-lain. Sedangkan kritis diartikan sebagai suatu keadaan seseorang untuk menentukan benar atau tidaknya suatu permasalahan yang dihadapi (KBBI, 2019).

Berpikir kritis dapat berupa suatu kegiatan yang dilakukan secara aktif dan terampil dalam melakukan suatu observasi dan komunikasi atau dalam memperoleh informasi maupun melakukan. argumentasi [6]. Berpikir kritis juga dapat diartikan suatu kegiatan yang membuat siswa dapat menentukan pilihan dan menarik kesimpulan dengan cerdas melalui proses menganalisis suatu permasalahan yang ada
[7]. Oleh karena itu, kemampuan berpikir kritis juga merupakan komponen dari kemampuan berpikir tingkat tinggi [7], [8]. Sedangkan menurut Ennis dalam [1], [9] menjelaskan bahwa suatu proses yang memiliki tujuan agar seseorang dapat membuat suatu keputusan terbaik sehingga hasilnya dapat dilakukan dengan benar juga merupakan suatu kegiatan berpikir kritis. Berdasarkan pendapat beberapa para ahli di atas dapat disimpulkan bahwa berpikir kritis adalah suatu kegiatan yang terorganisasi dan memiliki peran dalam proses menentukan pilihan yang terbaik dalam menyelesaikan suatu permasalahan.

Ennis dalam [10], [11] mengembangkan dua belas indikator dari berpikir kritis yang dirangkum menjadi lima aspek yaitu; (1) memberikan penjelasan secara sederhana, (2) menentukan dasar pengambilan keputusan, (3) menarik kesimpulan, (4) memberikan penjelasan lanjut, dan (5) memperkirakan dan menggabungkan. Sedangkan indikator-indikator keterampilan berpikir kritis pada tiap-tiap tahapan seperti pada Tabel 1 .

Tabel 1. Indikator berpikir kritis

\begin{tabular}{|c|c|c|}
\hline No & Aspek Keterampilan Berpikir Kritis & Indikator \\
\hline 1 & $\begin{array}{l}\text { Elementary Clarification (memberikan } \\
\text { penjelasan sederhana) }\end{array}$ & $\begin{array}{l}\text { a. Memfokuskan atau merumuskan pertanyaan. } \\
\text { b. Menganalisis argument } \\
\text { c. Mengklarifikasi dengan menanyakan dan } \\
\text { menjawab pertanyaan. }\end{array}$ \\
\hline 2 & $\begin{array}{l}\text { The Basis for the Decisions } \\
\text { (menentukan dasar pengambilan } \\
\text { keputusan) }\end{array}$ & $\begin{array}{l}\text { a. Mempertimbangkan kebenaran sumber } \\
\text { b. Melakukan observasi dan menilai laporan hasil } \\
\text { observasi }\end{array}$ \\
\hline 3 & $\begin{array}{c}\text { Inference } \\
\text { (menarik kesimpulan) }\end{array}$ & $\begin{array}{l}\text { a. Membuat deduksi dan mempertimbangkan } \\
\text { hasilnya. } \\
\text { b. Membuat induksi dan mempertimbangkan } \\
\text { hasilnya. } \\
\text { c. Membuat dan menentukan pertimbangan diri. }\end{array}$ \\
\hline 4 & $\begin{array}{l}\text { Advances Clarification (memberikan } \\
\text { penjelasan lanjut) }\end{array}$ & $\begin{array}{l}\text { a. Mendefinisikan dan mempertimbangkannya. } \\
\text { b. Mengidentifikasi asumsi. }\end{array}$ \\
\hline 5 & $\begin{array}{c}\text { Supposition and Integration } \\
\text { (memperkirakan dan menggabungkan) }\end{array}$ & $\begin{array}{l}\text { a. Mempertimbangkan alasan. } \\
\text { b. Menggabungkan informasi atau memadukan } \\
\text { dalam penentuan keputusan. }\end{array}$ \\
\hline
\end{tabular}

Dunia pendidikan, menganalisis dan menginterpretasi suatu data merupakan cerminan dari kegiatan berpikir kritis. Seperti yang telah dijelaskan oleh The 
Secretary's Commission on Achieving Necessary Skills pada tahun 1990 dalam [12] bahwa kompetensi berpikir kritis, membuat keputusan, problem solving, dan bernalar sebagai suatu komponen yang sangat penting dan digunakan dalam prestasi di dunia kerja. Oleh karena itu, mahasiswa prodi pendidikan fisika FMIPA UM sebagai calon tenaga pendidik diharapkan untuk memiliki kemampuan dasar seperti keterampilan berpikir kritis, keterampilan penyelesaian masalah, keterampilan pengambilan keputusan dan keterampilan berpikir kreatif sebagai bekal untuk terjun ke dunia kerja nantinya.

Penelitian yang mengkaji tentang kemampuan berpikir kritis saat ini tidaklah sedikit. Dimana dalam proses pengkajian, pastinya dibutuhkan suatu instrumen yang dapat mengukur kemampuan berpikir kritis secara tepat. Menurut Ennis dalam [13], dengan menggunakan tes kemampuan berpikir kritis seseorang dapat diukur. Tes ini dapat berupa tes pilihan ganda beralasan, tes keterampilan maupun tes uraian. Pada penelitian kali ini tes yang digunakan untuk mengukur kemampuan berpikir kritis mahasiswa adalah tes uraian yang disesuaikan dengan indikator berpikir kritis.

Sebelumnya, Ennis [14] sudah mengembangkan bentuk tes uraian secara umum untuk mengukur tingkat berpikir kritis. Selain itu, Syahbana [1] juga telah mengembangkan perangkat pembelajaran berbasis CTL untuk mengukur kemampuan berpikir kritis matematis siswa SMP, Amalia \& Susilaningsih [15] pada materi asam basa, Hartini \& Sukardjo [16] mengembangkan higher order thinking multiple choice test (HOT-MCT) untuk mengukur keterampilan berpikir kritis IPA, dan Pradana, Parno, \& Handayanto [13] pada materi optik geometri. Sedangkan tes berpikir kritis materi kinematika untuk mahasiswa fisika masih belum ada. Berdasarkan uraian tersebut maka dilakukanlah penelitian dan pengembangan untuk mengembangkan instrumen tes kemampuan berpikir kritis mahasiswa fisika Universitas Negeri Malang pada materi kinematika.

\section{METODE}

Penelitian yang dilakukan adalah jenis penelitian \& pengembangan model ADDIE dari Branch [17]. Jenis penelitian dan pengembangan model ADDIE ini memiliki lima tahapan dalam pelaksanaannya, yaitu: (1) analyze (penganalisisan), (2) design (perencanaan), (pengembangan), develop (pengimplementasian), dan (5) evaluate (pengevaluasian). Namun, penelitian ini dibatasi sampai tahap pengimplementasian.

Lokasi pengambilan data bertempat di Universitas Negeri Malang. Subjek penelitian dipilih dengan menggunakan teknik random sampling. Sehingga diperoleh subjek penelitiannya yaitu mahasiswa dari prodi pendidikan fisika angkatan 2018 FMIPA UM sebanyak 49 mahasiswa yang telah melaksanakan mata kuliah fisika dasar. Lama waktu yang diperlukan untuk melaksanakan penelitian adalah tiga bulan (bulan September sampai November 2019).

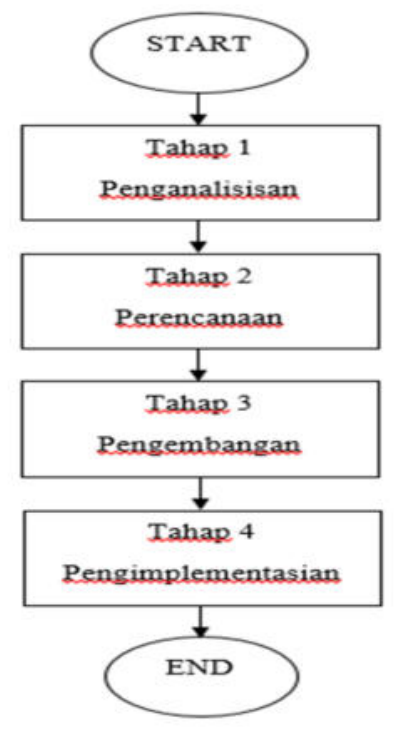

Gambar 1. Diagram Alur Tahapan Pengembangan Model ADDIE 
Tahap pertama adalah penganalisisan. Yaitu dengan melakukan penganalisisan instrument tes pengukuran kemampuan berpikir kritis yang sudah diteliti oleh peneliti terdahulu. Dari penganalisisan ini diketahui bahwa tes berpikir kritis materi kinematika untuk mahasiswa fisika masih belum ada. Oleh karena itulah dilakukanlah penelitian dan pengembangan instrumen tes kemampuan berpikir kritis mahasiswa pada materi kinematika.

Tahap kedua adalah perencanaan. Yaitu dilakukan dengan menetapkan patokan untuk penelitian dan pengembangan instrumen tes kemampuan berpikir kritis. Peneliti memilih lima indikator berpikir kritis yang telah dikemukakan oleh Ennis sebagai patokan dalam mengembangkan instrumen tes kemampuan berpikir kritis.

Tahap ketiga adalah pengembangan. Kelima indikator yang dipilih adalah patokan dalam proses pengembangan instrumen tes kemampuan berpikir kritis. Pada penelitian ini akan dikembangkan lima butir soal uraian. Masing-masing butir soal akan mewakili masing-masing indikator kemampuan berpikir kritis yang dijadikan patokan dalam membuat instrumen tes. Kelima indikator keterampilan berpikir kritis dan detail butir soal yang mewakilinya seperti yang disajikan pada Tabel 2.

\section{Tabel 2. Lima Indikator Berpikir Kritis} dan Rincian Butir Soal

\begin{tabular}{clc}
\hline No & \multicolumn{1}{c}{ Indikator Berpikir Kritis } & $\begin{array}{c}\text { Butir } \\
\text { Soal }\end{array}$ \\
\hline 1 & Menganalisis argument & 1 \\
2 & Membuat deduksi & 2 \\
3 & Membuat induksi & 3 \\
4 & Bertanya dan menjawab & \\
5 & pertanyaan klasifikasi & 4 \\
\hline
\end{tabular}

Selanjutnya, instrumen tersebut divalidasi oleh para ahli. Validasi isi dilakukan oleh dua dosen Jurusan Fisika
FMIPA Universitas Negeri Malang. Validasi isi meliputi beberapa kriteria, yaitu (1) kesesuaian butir soal dengan indikator penilaian, (2) batasan pertanyaan pada soal yang diharapkan sudah jelas, (3) soal yang disajikan benar secara konsep, (4) keterangan pada soal disajikan secara jelas, (5) rumusan soal menggunakan bahasa yang sederhana, (6) rumusan soal sudah komunikatif, (7) rumusan soal tidak menggunakan kata-kata/kalimat yang menimbulkan penafsiran, dan (8) butir soal menggunakan Bahasa Indonesia yang baik dan benar. Validasi isi dilakukan agar mendapat saran dari para ahli. Kemudian butir soal tes direvisi sesuai dengan saran para ahli. Selanjutnya hasil validasi isi juga dianalisis menggunakan metode deskriptif rata-rata.

Setelah validasi isi, dilakukan validasi emipiris. Validasi ini dilakukan terhadap mahasiswa S1 Pendidikan Fisika Universitas Negeri Malang angkatan 2018 sebanyak 49 mahasiswa yang dipilih secara acak. Validasi ini dilakukan untuk mengetahui validitas dan reliabilitas dari butir soal pada instrumen tes kemampuan berpikir kritis. Validasi soal ini kemudian dihitung dengan menggunakan perhitungan koefisien korelasional antara skor tiap butir soal dengan total skor yang diperoleh. Butir soal instrumen tes kemampuan berpikir kritis dikatakan valid apabila nilai $r_{\text {hitung }}>$ $r_{\text {tabel }}$. Kemudian untuk menentukan reliabilitas butir soal dilakukan perhitungan dengan cara perhitungan Cronbach Alpha.

Tahap keempat adalah pengimplementasian. Dimana nantinya instrumen tes yang sudah diketahui nilai validitas maupun reliabilitasnya digunakan untuk pengukuran kemampuan berpikir kritis mahasiswa fisika yang berjumlah 49 mahasiswa. 


\section{HASIL DAN PEMBAHASAN}

\section{A. Validasi Isi}

Telah dijelaskan delapan kriteria dalam validasi isi dilakukan oleh para ahli yaitu oleh dua dosen Jurusan Fisika FMIPA Universitas Negeri Malang. Rekapitulasi hasil validasi isi ditunjukkan pada Tabel 3.

Dari Tabel 3, dapat diketahui bahwa kelima butir soal pada instrumen tes kemampuan berpikir kritis memiliki kriteria valid dengan rata-rata nilai yaitu 3,30. Dari nilai yang diperoleh ini menunjukkan bahwa instrumen soal ini dapat dan layak untuk digunakan dalam mengukur kemampuan berpikir kritis. Hal ini diperkuat oleh penelitian yang telah dilakukan oleh Pradana, Parno, \& Handayanto [13] yang mengembangkan instrumen soal dengan nilai rata-rata validasi isi sebesar 3,394 dan menunjukkan bahwa instrumen tersebut layak digunakan.

Tabel 3. Rekapitulasi Hasil Validasi Isi

\begin{tabular}{|c|c|c|c|c|c|c|c|c|c|c|}
\hline \multicolumn{11}{|c|}{ Pernyataan } \\
\hline $\begin{array}{l}\text { Butir } \\
\text { Soal }\end{array}$ & $\begin{array}{c}\text { Butir } \\
\text { soal } \\
\text { sesuai } \\
\text { dengan } \\
\text { indikator } \\
\text { penilaian }\end{array}$ & $\begin{array}{c}\text { Batasan } \\
\text { pertanyaan } \\
\text { yang } \\
\text { diharapkan } \\
\text { sudah jelas }\end{array}$ & $\begin{array}{c}\text { Butir } \\
\text { soal } \\
\text { yang } \\
\text { disajikan } \\
\text { benar } \\
\text { secara } \\
\text { konsep } \\
\end{array}$ & $\begin{array}{c}\text { Keterangan } \\
\text { pada soal } \\
\text { disajikan } \\
\text { secara jelas }\end{array}$ & $\begin{array}{c}\text { Rumusan } \\
\text { butir soal } \\
\text { menggunakan } \\
\text { bahasa yang } \\
\text { sederhana }\end{array}$ & $\begin{array}{l}\text { Rumusan } \\
\text { soal sudah } \\
\text { komunikatif }\end{array}$ & $\begin{array}{c}\text { Rumusan soal tidak } \\
\text { menggunakan kata- } \\
\text { kata/kalimat yang } \\
\text { menimbulkan } \\
\text { penafsiran ganta } \\
\text { atau salah } \\
\text { pengertian } \\
\end{array}$ & $\begin{array}{c}\text { Butir soal } \\
\text { menggunakan } \\
\text { Bahasa } \\
\text { Indonesia } \\
\text { yang baik dan } \\
\text { benar }\end{array}$ & $\begin{array}{c}\text { Rata- } \\
\text { rata }\end{array}$ & Ket. \\
\hline 1 & 4 & 3 & 4 & 3 & 3 & 3 & 4 & 3 & 3,375 & valid \\
\hline 2 & 4 & 3 & 4 & 3 & 3 & 3 & 4 & 3 & 3,375 & valid \\
\hline 3 & 4 & 3 & 3 & 3 & 3 & 3 & 3 & 3 & 3,125 & valid \\
\hline 4 & 4 & 3 & 3 & 3 & 3 & 3 & 3 & 3 & 3,125 & valid \\
\hline 5 & 4 & 3 & 4 & 3 & 3 & 4 & 3 & 4 & 3,5 & valid \\
\hline $\begin{array}{c}\text { Rata- } \\
\text { rata }\end{array}$ & 4 & 3 & 3,6 & 3 & 3 & 3,2 & 3,4 & 3,2 & 3,3 & valid \\
\hline
\end{tabular}

Revisi instrumen tes kemampuan berpikir kritis dilakukan berdasarkan hasil validasi isi. Tabel 4 merupakan salah satu contoh hasil revisi pada butir soal. Berdasarkan validasi isi kelima butir soal masuk dalam kategori baik, namun masih belum bisa disimpulkan bahwa instrumen soal yang telah dikembangkan telah dapat dipercaya dan memiliki keajegan untuk digunakan. Sebab validasi isi hanya terbatas pada kesesuaian antara materi yang digunakan dalam instrumen tes dengan indikator dari berpikir kritis. Sehingga, perlu dilakukan uji validitas lebih lanjut untuk mengetahui tingkat validitas dan reliabilitas dari instrumen tes kemampuan berpikir kritis.

Tabel 4. Contoh Revisi Terhadap Butir Soal

\begin{tabular}{|c|c|c|c|c|c|}
\hline \multirow{4}{*}{$\begin{array}{l}\text { Mengemukakan } \\
\text { adanya } \\
\text { hubungan } \\
\text { waktu dan } \\
\text { ketinggian dari } \\
\text { suatu benda }\end{array}$} & \multirow{4}{*}{$\begin{array}{l}\text { Bertanya dan } \\
\text { menjawab } \\
\text { pertanyaan } \\
\text { klarifikasi } \\
\text { dan/atau } \\
\text { pertanyaan } \\
\text { yang } \\
\text { menantang }\end{array}$} & \multirow{4}{*}{$\begin{array}{l}\text { Diberikan contoh } \\
\text { peristiwa penerapan } \\
\text { gaya vertical ke atas. } \\
\text { Siswa diminta } \\
\text { membuat pertanyaan } \\
\text { dari peristiwa } \\
\text { tersebut beserta } \\
\text { jawabannya. }\end{array}$} & \multirow{4}{*}{$\begin{array}{l}\text { 4. Pada waktu bersamaan } \\
\text { dua bola dilempar ke } \\
\text { atas. Kelajuan awal } \\
\text { bola A dan B berturut- } \\
\text { turut adalah } 10 \mathrm{~m} / \mathrm{s} \\
\text { dan } 20 \mathrm{~m} / \mathrm{s} \text {. Buatlah } \\
\text { pertanyaan beserta } \\
\text { jawabannya mengenai } \\
\text { peristiwa tersebut! }\end{array}$} & $\begin{array}{l}\text { Bola manakah yang mencapai } \\
\text { ketinggian maksimum lebih dulu? }\end{array}$ & 1 \\
\hline & & & & $\begin{array}{l}\text { Jawaban: } \\
\text { Bola yang mencapai ketinggian } \\
\text { maksimum lebih dulu yakni bola A. }\end{array}$ & 1 \\
\hline & & & & $\begin{array}{l}\text { Hal ini dapat disebabkan karena bola } \\
\text { A memiliki kecepatan yang lebih } \\
\text { kecil dari pada bola B. }\end{array}$ & 1 \\
\hline & & & & $\begin{array}{l}\text { Sehingga membutuhkan waktu yang } \\
\text { lebih sedikit untuk mencapai titik } \\
\text { tertingginya }\end{array}$ & 1 \\
\hline $\begin{array}{l}\text { Mengemukakan } \\
\text { adanya } \\
\text { hubungan } \\
\text { waktu dan } \\
\text { ketinggian dari } \\
\text { suatu benda }\end{array}$ & $\begin{array}{l}\text { Bertanya dan } \\
\text { menjawab } \\
\text { pertanyaan } \\
\text { klarifikasi } \\
\text { dan/atau } \\
\text { pertanyaan } \\
\text { yang } \\
\text { menantang }\end{array}$ & $\begin{array}{l}\text { Diberikan contoh } \\
\text { peristiwa penerapan } \\
\text { gaya vertical ke atas. } \\
\text { Siswa diminta } \\
\text { membuat pertanyaan } \\
\text { dari peristiwa } \\
\text { tersebut beserta } \\
\text { jawabannya. }\end{array}$ & $\begin{array}{l}\text { 4. Bola A dan bola B } \\
\text { dilempar ke atas secara } \\
\text { bermsaan dengan } \\
\text { kelajuan berturut-turut } \\
\text { adalah } 10 \mathrm{~m} / \mathrm{s} \text { dan } 20 \\
\mathrm{~m} / \mathrm{s} \text {. Buatlah pertanyaan } \\
\text { beserta jawabannya } \\
\text { mengenai peristiwa } \\
\text { tersebut! }\end{array}$ & $\begin{array}{l}\text { Siswa dapat membuat pertanyaan } \\
\text { yang sesuai dengan pernyataan dan } \\
\text { menjawab dengan tepat } \\
\text { CONTOH } \\
\text { Bola manakah yang mencapai } \\
\text { ketinggian maksimum lebih dulu? } \\
\text { Jawaban: } \\
\text { Bola yang mencapai ketinggian } \\
\text { maksimum lebih dulu yakni bola A. }\end{array}$ & 4 \\
\hline
\end{tabular}




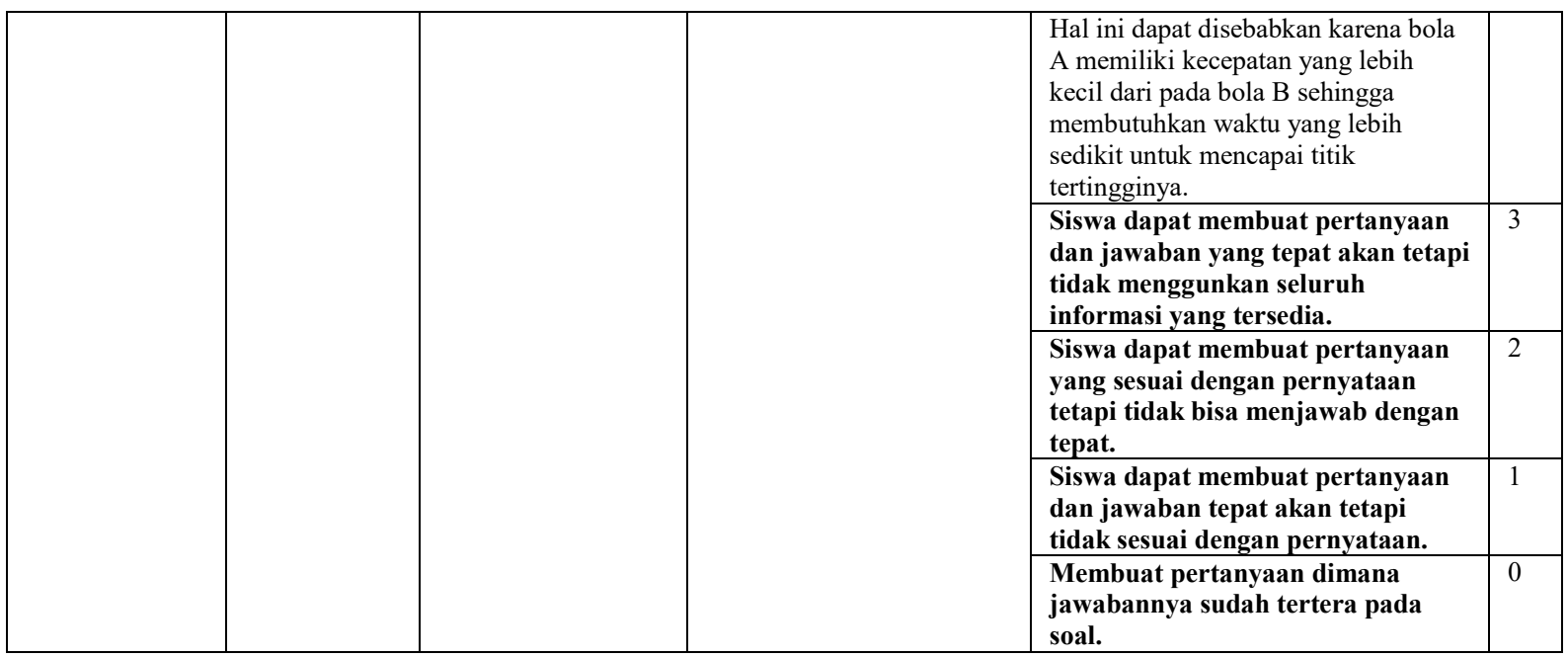

B. Validitas Empiris

Validitas empiris diperoleh dari 49 mahasiswa yang diminta untuk mengerjakan instrumen tes kemampuan berpikir kritis yang berjumlah lima soal secara mandiri dengan waktu 60 menit. Hasil pekerjaan mahasiswa ini kemudian dikoreksi berdasarkan rubrik penilaian yang telah dibuat dan dianalisis. Berikut hasil analisis validasi empiris dapat ditunjukkan pada Tabel 5.

Tabel 5. Hasil Analisis Validasi Empiris

\begin{tabular}{cccc}
\hline $\begin{array}{c}\text { Butir } \\
\text { Soal }\end{array}$ & $\boldsymbol{r}_{\text {hitung }}$ & $\begin{array}{c}\boldsymbol{r}_{\text {tabel }} \\
(\mathbf{n}=\mathbf{4 9})\end{array}$ & Keterangan \\
\hline 1 & 0,4210 & & valid \\
2 & 0,7304 & & valid \\
3 & 0,6667 & 0,2816 & Valid \\
4 & 0,6952 & & Valid \\
5 & 0,7212 & & Valid \\
\hline
\end{tabular}

Berdasarkan hasil analisis, diketahui bahwa kelima butir soal masuk dalam kategori valid. Hal ini berarti semua butir soal pada instumen yang telah dibuat dapat diaplikasikan dalam pengukuran kemampuan berpikir kritis mahasiswa pada materi kinematika. Namun, pada soal nomor 1 memiliki nilai validitas yang berbeda cukup jauh dengan soal nomor 2, 3, 4 dan 5. Melalui analisis jawaban pekerjaan mahasiswa, nalai validitas pada soal nomor 1 rendah karena permasalahan yang diberikan masih cukup mudah sehingga menyebabkan sebagian besar mahasiswa masih bisa menjawab soal dengan cukup baik meskipun tidak mendapatkan nilai yang sempurna.

Kelima butir soal ini telah mewakili indikator kemampuan berpikir kritis yang menjadi patokan dalam penyusunan instrumen tes kemampuan berpikir kritis. Indikator pertama yaitu menganalisis argumen terdapat pada soal nomor 1, indikator kedua membuat deduksi terdapat pada soal nomor 2, indikator ketiga membuat induksi terdapat pada soal nomor 3, indikator keempat bertanya dan menjawab pertanyaan terdapat pada soal nomor 4, dan indikator yang terakhir atau kelima mengidentifikasi asumsi-asumsi terdapat pada soal nomor 5 . 


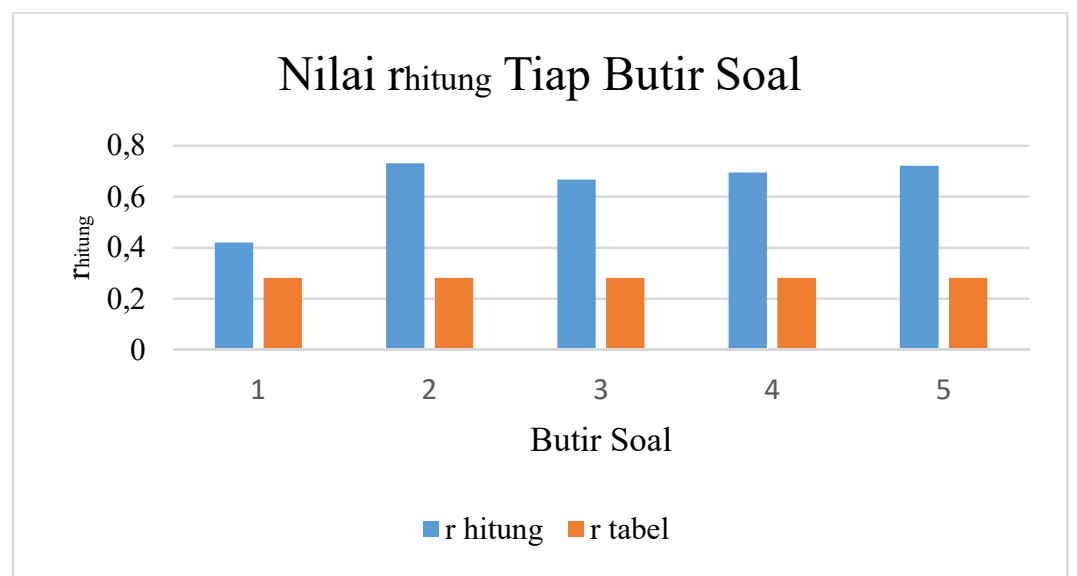

Gambar 2. Nilai Validitas Tiap Butir Soal

Setelah diketahui bahwa kelima butir soal valid, selanjutnya dilakukan uji reliabilitas guna mengetahui tingkat keajegan butir soal saat digunakan dalam proses pengukuran kemampuan berpikir kritis mahasiwa. Dari perhitungan yang telah dilakukan, nilai koefisien reliabilitas Cronbach Alpha yang diperoleh yaitu sebesar $r_{i i}=0,67$. Hal ini menunjukkan bahwa instrumen tes yang telah dikembangkan memiliki tingkat keajegan yang tinggi [18], sehingga instrumen tes ini dapat diaplikasikan dalam kegiatan pengukuran kemampuan berpikir kritis mahasiswa pada materi kinematika. Menurut Istiyono, Mardapi, \& Suparno dalam [13] baik tidaknya validitas dan reliabilitas dari suatu soal dipengaruhi oleh beberapa faktor, yaitu (1) butir soal dikembangkan sesuai dengan prosedur pengembangan, (2) acuan yang tepat dalam mengembangkan instrumen soal, validasi isi pada tiap butir soal, dan (4) kesungguhan responden dalam mengerjakan soal dan diawasi dengan ketat. Faktor-faktor tersebut yang mempengaruhi instrumen soal sehingga memiliki nilai validitas dan reliabilitas yang baik.

C. Hasil Implementasi Soal Tes

Implementasi pengembangan instrumen tes kemampuan berpikir kritis dilakukan dengan subjek 49 mahasiswa prodi S1 Pendidikan Fisika dengan hasil yang dapat dilihat pada Tabel 6 .
Tabel 6. Hasil Implementasi Instrumen Tes Berpikir Kritis

\begin{tabular}{lc}
\hline \multicolumn{1}{c}{ Aspek } & Nilai \\
\hline Jumlah responden & 49 \\
Nilai rata-rata & 9,71 \\
Standar Deviasi & 5,50 \\
Nilai Tertinggi & 20 \\
Nilai Terendah & 1 \\
Nilai Maksimum & 20 \\
\hline
\end{tabular}

Berdasarkan Tabel 5, diketahui bahwa tingkat kemampuan berpikir kritis mahasiswa fisika prodi S1 Pendidikan Fisika Universitas Negeri Malang angkatan 2018 masih tergolong rendah yang dapat dibuktikan dengan rata-rata nilai tes kemampuan berpikir kritis yang diperoleh pada penelitian ini adalah 9,71 dari skol 20. Hasil ini hampir sama dengan penelitian sebelumnya yang memperoleh hasil ratarata nilai tes kemampuan berpikir kritis mahasiswa pada materi optika geometri sebesar 27,20 dari skor 100 [13].

\section{SIMPULAN}

Berdasarkan hasil penelitian dan analisis data yang telah dilakukan, dapat disimpulkan bahwa kelima butir soal yang dikembangkan memiliki kategori valid $\left(r_{\text {hitung }}>r_{\text {tabel }}\right)$ dan memiliki tingkat reliabilitas Cronbach Alpha yaitu $r_{i i}=$ 0,67 . Kemudian pada hasil uji validitas dan reliabilitas, menunjukkan bahwa instrumen tes yang telah dikembangkan memiliki tingkat reliabilitas yang tinggi. Oleh karena 
itu, instrumen tes ini dapat digunakan dalam kegiatan pengukuran tingkat kemampuan berpikir kritis mahasiswa. Selain itu, kelima butir soal yang dikembangkan telah mewakili lima dari duabelas indikator berpikir kritis yang telah ditetapkan sebagai dasar dalam penyusunan instrumen tes kemampuan berpikir kritis.

Instrumen ini kemudian digunakan untuk mengukur tingkat kemampuan berpikir kritis mahasiswa. Banyaknya responden yang digunakan adalah 49 mahasiswa fisika prodi S1 Pendidikan Fisika Universitas Negeri Malang angkatan 2018. Dari hasil uji coba instrumen tes ini didapatkan hasil nilai rata-rata yang dicapai mahasiswa sebesar 9,71. Dengan nilai tertingginya adalah 20 dan nilai terendahnya $1\left(S_{D}=\right.$ $5,50)$. Berdasarkan hasil tersebut, maka dapat disimpulkan bahwa tingkat kemampuan berpikir kritis mahasiswa masih tergolong rendah.

\section{DAFTAR PUSTAKA}

[1] M. Mujib, "Penjenjangan Kemampuan Berpikir Kritis Matematis Berdasarkan Teori Bloom Ditinjau Dari Kecerdasan Multiple Intelligences," Desimal J. Mat., vol. 2, no. 1, pp. 87-103, 2019.

[2] D. A. I. Wijayanti, K. Pudjawan, and I. G. Margunayasa, "Analisis Kemampuan Berpikir Kritis Siswa Kelas V Dalam Pembelajaran IPA Di SD No. 1, 2, dan 3 Kaliuntu Gugus X Kecamatan Buleleng," Mimb. PGSD Undiksha, vol. 3, no. 1, 2015.

[3] D. Hidayanti, A. R. As'ari, and C. Daniel, "Analisis Kemampuan Berpikir Kritis Siswa SMP Kelas IX Pada Materi Kesebangunan,” 2016.

[4] I. H. Abdullah, "Berpikir kritis Matematik," Delta-Pi J. Mat. Dan Pendidik. Mat., vol. 2, no. 1, 2016.

[5] "Arti kata kritis-2 - Kamus Besar Bahasa Indonesia (KBBI) Online." [Online]. Available: https://kbbi.web.id/kritis-2.

[Accessed: 23-Nov-2019].

[6] N. Fatimah, G. Gunawan, and W. Wahyudi, "Pembelajaran Berbasis Masalah Dengan Strategi Konflik Kognitif Terhadap Penguasaan Konsep dan Kemampuan Berpikir Kritis Fisika Siswa Kelas XI SMKN 1 Lingsar Tahun Pelajaran 2015/2016," J. Pendidik. Fis. Dan Teknol., vol. 2, no. 4, pp. 183-190, 2017.

[7] I. D. Kurniawati and M. Diantoro, "Pengaruh Pembelajaran Inkuiri Terbimbing Integrasi Peer Instruction Terhadap Penguasaan Konsep dan Kemampuan Berpikir Kritis Siswa," $J$. Pendidik. Fis. Indones., vol. 10, no. 1, 2014.

[8] S. K. J. A. Rudnick, "The New Sourcebook For Teaching Reasoning and Problem Solving in Junior and Senior High School," 1996.

[9] W. Pertiwi, "Analisis Kemampuan Berpikir Kritis Matematis Peserta Didik SMK Pada Materi Matriks," J. Pendidik. Tambusai, vol. 2, no. 4, pp. 821-831, 2018.

[10] L. Anggraeni, "Penerapan Metode Studi Kasus Dalam Upaya Meningkatkan Kemampuan Berpikir Kritis Mahasiswa Pada Mata Kuliah Hubungan Internasional," Media Komun. FIS, vol. 11, no. 3, 2012.

[11] A. L. Costa, Developing Minds: A Resource Book For Teaching Thinking. ERIC, 1985.

[12] A. W. Kurniasih, "Penjenjangan Kemampuan Berpikir Kritis Mahasiswa Prodi Pendidikan Matematika FMIPA UNNES dalam Menyelesaikan Masalah Matematika," in Seminar Nasional Matematika dan Pendidikan Matematika, Prodi Pendidikan Matematika FMIPA UNY, Yogyakarta, 2010.

[13] S. D. S. Pradana, P. Parno, and S. K. Handayanto, "Pengembangan Tes Kemampuan Berpikir Kritis Pada 
Materi Optik Geometri Untuk Mahasiswa Fisika," J. Penelit. Dan Eval. Pendidik., vol. 21, no. 1, pp. 5164, 2017.

[14] "Ennis, R. H. (1993). Critical Thinking Assessment.... - Google Cendekia." Diakses melalui https://scholar.google.co.id/scholar?h $l=i d \& a s \_s d t=0 \% 2 C 5 \& q=$ Ennis $\% 2 C$ $+R .+H .+\% 281993 \% 29 .+$ Critical + thi nking + assessment. + Theory + Into $+\mathrm{Pr}$ actice $\% 2 \mathrm{C}+$ Vol. $+32 \% 2 \mathrm{C}+\mathrm{No} .+3 \% 2$ $C+p p .+179-186 . \& b \operatorname{tn} G=$ : tanggal 25 November 2019.

[15] N. F. Amalia and E. Susilaningsih, "Pengembangan Instrumen Penilaian Keterampilan Berpikir Kritis Siswa SMA Pada Materi Asam Basa," $J$. Inov. Pendidik. Kim., vol. 8, no. 2, 2014.

[16] H. Hartini and S. Sukardjo, "Pengembangan Higher Order Thinking Multiple Choice Test Untuk Mengukur Keterampilan Berpikir
Kritis IPA Kelas VII SMP/MTs," $J$. Inov. Pendidik. IPA, vol. 1, no. 1, pp. 86-101, 2015.

[17] "Branch, R. M. (2009). Instructional Design: The ADDIE... - Google Cendekia." Diakses melalui https://scholar.google.co.id/scholar?h $l=i d \& a s \_s d t=0 \% 2 C 5 \& q=$ Branch $\% 2$ $C+R .+\bar{M} .+\% 282009 \% 29 .+$ Instructio nal + Design $\% 3 A+$ The + ADDIE + Appr oach + New + York $\% 3 A+$ Springer $+\mathrm{Ne}$ $w+$ York.\&btn $G=$ : tanggal 25 November 2019.

[18] S. Sofiyah and S. S. Susanto, "Pengembangan Paket Tes Kemampuan Berpikir Tingkat Tinggi Matematika Berdasarkan Revisi Taksonomi Bloom Pada Siswa Kelas V SD," Program Studi Pendidik. Mat. Jur. P MIPA FKIP Univ. Jember, 2015. 